\title{
Genetic parameters for body condition score, locomotion, angularity, and production traits in Italian Holstein cattle
}

\author{
M. Battagin, ${ }^{* 1}$ C. Sartori, ${ }^{*}$ S. Biffani, $\dagger^{2}$ M. Penasa, ${ }^{*}$ and M. Cassandro* \\ *Department of Agronomy, Food, Natural Resources, Animals and Environment, University of Padova, Viale dell'Università 16, 35020 Legnaro, \\ Italy \\ †Associazione Nazionale Allevatori Frisona Italiana, 26100 Cremona, Italy
}

\section{ABSTRACT}

The objectives of this research were to estimate genetic parameters for body condition score (BCS) and locomotion (LOC), and to assess their relationships with angularity (ANG), milk yield, fat and protein content, and fat to protein content ratio $(\mathrm{F}: \mathrm{P})$ in the Italian Holstein Friesian breed. The Italian Holstein Friesian Cattle Breeders Association collects type trait data once on all registered first lactation cows. Body condition score and LOC were introduced in the conformation scoring system in 2007 and 2009, respectively. Variance (and covariance) components among traits were estimated with a Bayesian approach via a Gibbs sampling algorithm and an animal model. Heritability estimates were 0.114 and 0.049 for BCS and LOC, respectively. The genetic correlation between BCS and LOC was weak $(-0.084)$ and not different from zero; therefore, the traits seem to be genetically independent, but further investigation on possible departures from linearity of this relationship is needed. Angularity was strongly negatively correlated with BCS (-0.612), and strongly positively correlated with LOC (0.650). The genetic relationship of milk yield with BCS was moderately negative $(-0.386)$, and was moderately positive $(0.238)$ with LOC. These results indicate that high-producing cows tend to be thinner and tend to have better locomotion than low-producing cows. The genetic correlation of BCS with fat content (0.094) and F:P (-0.014) was very weak and not different from zero, and with protein content (0.173) was weak but different from zero. Locomotion was weakly correlated with fat content (0.071), protein content (0.028), and $\mathrm{F}: \mathrm{P}$ (0.074), and correlations were not different from zero. Phenotypic correlations were generally weaker than their genetic counterparts, ranging from -0.241 (BCS with ANG) to 0.245 (LOC with ANG). Before

Received November 6, 2012.

Accepted April 15, 2013.

${ }^{1}$ Corresponding author: mara.battagin@studenti.unipd.it

${ }^{2}$ Current address: Istituto di Biologia e Biotecnologia Agraria (IBBA), Consiglio Nazionale delle Ricerche, 26900 Lodi, Italy. including BCS and LOC in the selection index of the Italian Holstein breed, the correlations with other traits currently used to improve type and functionality of animals need to be investigated.

Key words: body condition score, locomotion, angularity, genetic parameter

\section{INTRODUCTION}

The Italian Holstein Friesian Cattle Breeders Association (ANAFI; Cremona, Italy) has been collecting data on conformation traits since 1971. Initially, the evaluation consisted of assigning a score to several anatomical regions of the cow and a final overall merit score. In 1984, the linear system was introduced with the aim of objectively describing the conformation of the animal, from one biological extreme to the other, and a 1- to 50-point scale system was adopted (ANAFI, 2012b). In 1993, the conformation scoring system was updated again using the guidelines provided by the World Holstein Friesian Federation (WHFF, 2008). Body condition score and locomotion (LOC) were introduced in the Italian linear trait classification program in 2007 and 2009, respectively. Currently, all first lactation cows belonging to registered herds are evaluated once for 21 type traits, including BCS and LOC.

Body condition score is a visual measure of fat covering the pelvic and lumbar regions; its scoring is based on a 1 (very thin) to 5 (very fat) scale with 0.25 -point increments. In particular, the fat reserves of the thurl region, the angularity of hips and pins, and the prominence of spinous processes are evaluated (Edmonson et al., 1989; ANAFI, 2012b). Body condition score has gained notable interest in recent decades as an important management tool in the dairy herd because it can be used both as indicator of the overall energy status and predictor of reproduction, health, and welfare of the cow (Roche et al., 2009; Zink et al., 2011). Some countries (including Italy) do not have a national genetic evaluation for BCS. Indeed, angularity (ANG) is currently used by the majority of the countries as the best predictor of BCS in the international genetic evaluation for the Holstein breed (Battagin et 
al., 2012). Angularity is defined as the angle and spring of the ribs, ranging from 1 , for a cow lacking angularity with closed ribs, to 50, for a very angular cow with open ribs (WHFF, 2008).

Locomotion evaluates the length of the step and direction of rear legs in movement and is scored on a 1 (lame) to 50 (excellent) scale, with 1-unit increments: a score of 5 is given to short strides and severe abduction; a score of 25 is given to normal strides and slight abduction; and scores greater than 40 are given to long strides without abduction (ANAFI, 2012b). The direction of the scale follows the guidelines of WHFF (2008), and it is the opposite of those reported in the literature (Manson and Leaver, 1988; Boettcher et al., 1998; Van Dorp et al., 2004). Locomotion has been defined and investigated since the 1980s as a predictor of lameness, reproductive performance, and foot and leg diseases, all of which could be responsible for reduction of animal welfare, economic losses for the farmer, and involuntary culling (Boettcher et al., 1998; van der Waaij et al., 2005; Onyiro et al., 2008). Locomotion entered the Interbull portfolio in 2009, but 6 out of 10 countries that started the international evaluation for this trait use other related type traits (e.g., rear leg set, rear view, or feet and legs) as best predictors (Interbull, 2012a).

The aims of this study were to estimate genetic parameters for BCS and LOC in the Italian Holstein population and to assess their phenotypic and genetic correlations with ANG and production traits. If BCS and LOC are heritable, they may be included in future breeding strategies to improve these traits in the Italian Holstein population.

\section{MATERIALS AND METHODS}

\section{Data and Editing}

Information on BCS and ANG was gathered from July 2007 to June 2012, and on LOC from February 2009 to June 2012, and were recorded by ANAFI once for first lactation cows. Only animals with known parents and between 20 and 38 mo of age at scoring were retained in the data set. Herd-year-season (HYS) classes were formed and those including less than 5 cows were discarded. Also, records from classifiers who scored less than 100 animals were removed. The date of scoring of BCS and LOC for a given cow was matched with the closest test-day milk record if a milk record within $16 \mathrm{~d}$ of the BCS or LOC scoring date existed (similar to Dal Zotto et al., 2007). A test-day milk record included data on milk yield (MY; $\mathrm{kg} / \mathrm{d}$ ), fat and protein content (\%), and fat to protein content ratio $(\mathbf{F}: \mathbf{P})$. Test-day milk records falling outside the mean $\pm 3.5 \mathrm{SD}$ were discarded from the data set.
Following editing of the data as above, 500,053 records were available for further analyses. To reduce computer memory and time requirements, 5 samples of 1,000 herds each were randomly selected using the SURVEYSELECT procedure of SAS (SAS Institute Inc., Cary, NC). Means and variances of the traits were very similar across samples, and a preliminary assessment of variance components showed that estimates of genetic and phenotypic parameters were very comparable among samples (data not shown); therefore, only results from 1 data set (DATA1) were reported. Because the recording of LOC started $1.5 \mathrm{yr}$ later than that of BCS, fewer records were available for this trait. Hence, a subset of LOC records (DATA2) was extracted from DATA1, and cows included in classes of HYS and classifier with less than 5 and 100 contemporary animals, respectively, were removed from the data set. Table 1 summarizes the descriptive statistics of the data before and after sampling. Sampled herds accounted for 66,808 and 44,218 cows, progeny of 4,982 and 3,799 sires, and were spread over 4,296 and 2,676 classes of HYS in DATA1 and DATA2, respectively. Animals were scored by 31 (DATA1) and 27 (DATA2) classifiers. The pedigree files for the analysis included animals with phenotypic records and all of their known ancestors up to 10 generations, and resulted in 253,602 animals for DATA1 and 197,787 animals for DATA2.

\section{Parameter Estimation}

Heritability estimates were obtained under singletrait animal models, using DATA1 for BCS, ANG, MY, fat content, protein content, and F:P, and DATA2 for LOC. The fixed systematic effects considered in the analyses were age of the cow at scoring (19 classes of 1 month each, from 20-38 mo), DIM (12 classes, the first being a class from 5-30 d, the central being classes of $30 \mathrm{~d}$ each, and the last being a class from 335-364 d), classifier (31 classifiers for BCS and ANG, and 27 for LOC), and MY (4 classes: $<25 \mathrm{~kg} / \mathrm{d}, 25-29 \mathrm{~kg} / \mathrm{d}, 30-33$ $\mathrm{kg} / \mathrm{d}$, and $>34 \mathrm{~kg} / \mathrm{d}$ ). The classifier and MY effects were not included in the analysis of production traits. The general form of the model was as follows:

$$
\mathbf{y}=\mathbf{X} \boldsymbol{\beta}+\mathbf{Z}_{1} \text { hys }+\mathbf{Z}_{2} \mathbf{c l}+\mathbf{Z}_{3} \mathbf{a}+\mathbf{e},
$$

where $\mathbf{y}$ was the vector of observations for BCS, ANG, LOC, MY, fat content, protein content, or F:P; $\boldsymbol{\beta}$ was the vector of fixed effects as previously described; hys was the vector of random effect of herd-year-season of classification; cl was the vector of random effect of classifier; a was the vector of random effect of additive genetic animal; and $\mathbf{e}$ was the vector of random residuals. $\mathbf{X}$ and $\mathbf{Z}_{i}(i=1-3)$ were incidence matrices of appropri- 
Table 1. Means (SD) for BCS, locomotion, angularity, milk yield, fat and protein contents, and fat to protein ratio $(\mathrm{F}: \mathrm{P})$ of data before and after sampling

\begin{tabular}{lrrr}
\hline Trait & $\begin{array}{c}\text { Before sampling } \\
(\mathrm{n}=500,053)^{1}\end{array}$ & $\begin{array}{c}\text { DATA1 }^{2} \\
(\mathrm{n}=66,808)\end{array}$ & \multicolumn{1}{c}{$\begin{array}{c}\text { DATA2 }^{3} \\
(\mathrm{n}=44,218)\end{array}$} \\
\hline BCS & $3.01(0.46)$ & $3.01(0.46)$ & $2.99(0.46)$ \\
Locomotion & $23.46(6.27)$ & $23.49(6.19)$ & $23.48(6.19)$ \\
Angularity & $28.09(5.15)$ & $28.05(5.14)$ & $28.29(5.16)$ \\
Milk yield $(\mathrm{kg} / \mathrm{d})$ & $30.48(6.65)$ & $30.28(6.63)$ & $30.62(6.63)$ \\
Fat $(\%)$ & $3.59(0.72)$ & $3.59(0.72)$ & $3.60(0.74)$ \\
Protein $(\%)$ & $3.33(0.33)$ & $3.33(0.33)$ & $3.33(0.33)$ \\
F:P & $1.08(0.21)$ & $1.08(0.21)$ & $1.08(0.21)$ \\
\hline
\end{tabular}

${ }^{1} \mathrm{n}=331,654$ for locomotion.

${ }^{2}$ DATA1 was used for the analysis of BCS, angularity, and milk traits.

${ }^{3}$ DATA2 was used for the analysis of locomotion.

ate order relating the corresponding effects to the dependent variable. The random effects hys, $c l, a$, and $e$ were assumed to be normally distributed with null means and to be mutually uncorrelated. Genetic effects $a$ were correlated between relatives and had variance $\mathbf{A} \sigma_{a}^{2}$, where $\mathbf{A}$ was the additive genetic relationship matrix among animals and $\sigma_{a}^{2}$ was the genetic variance for animal effects. Nongenetic effects hys, $c l$, and $e$ were uncorrelated between animals, with variances $\sigma_{\text {hys }}^{2}, \sigma_{c l}^{2}$, and $\sigma_{e}^{2}$, respectively.

Genetic and phenotypic correlations between pairs of traits were assessed through bivariate animal models, using the same data sets as the previous analysis. Systematic and random effects were identical to the univariate approach, and for each random effect a (co) variance structure between traits was assumed.

Variance (and covariance) components were estimated with a Bayesian approach via Gibbs sampling algorithm (Geman and Geman, 1984) using the GIBBS3F90 program (Misztal, 2008). The Gibbs sampler performed 480,000 iterations and the initial 30,000 samples were discarded as burn-in. The posterior means of (co)variance components were estimated using 4,500 samples (i.e., 1 every 100 samples of the remaining 450,000 iterations). The convergence of Gibbs samples was assessed by visual inspection of trace plots. The posterior mean was used as a point estimate of (co)variance components and related parameters. Lower and upper limits of the $95 \%$ highest probability density region for the posterior SD (PSD95\%) for variance components, heritabilities, and phenotypic and genetic correlations were estimated from the Gibbs samples.

Heritability was defined as the ratio of additive genetic variance to phenotypic variance, which was the sum of additive genetic, HYS, classifier, and residual variances for BCS, LOC, and ANG, and the sum of additive genetic, HYS, and residual variances for MY, fat and protein contents, and F:P. Within-herd heritability was also computed as the ratio of additive genetic variance to the sum of additive and residual variances, as this parameter is commonly used in practice selection. Additive genetic correlations were the ratio of the covariance of 2 traits to the product of their additive genetic SD. Finally, phenotypic correlations were computed as the ratio of phenotypic covariance of 2 traits to the product of their phenotypic SD.

\section{RESULTS}

\section{Descriptive Statistics}

Means and SD for the analyzed traits were very similar before and after sampling (Table 1). Before sampling, means (SD) for BCS, LOC, and ANG were 3.01 (0.46), 23.46 (6.27), and 28.09 (5.15), respectively; LOC had the highest coefficient of variation $(27 \%)$ followed by ANG (18\%) and BCS (15\%). Milk yield, fat content, protein content, and F:P averaged $30.48(6.65) \mathrm{kg} / \mathrm{d}$, $3.59 \%(0.72 \%), 3.33 \%(0.33 \%)$, and $1.08(0.21)$, respectively, in agreement with the official statistics reported by ANAFI (2012a). The distributions of BCS, LOC, and ANG followed a normal distribution, as shown in Figure 1. About $28 \%$ of cows were scored 3.25 for BCS. The distributions of LOC and ANG showed greater variation than that of BCS, and approximately $14 \%$ of cows received a score of 25 for these traits. Locomotion had in prevalence scores lower than 25, whereas ANG had the opposite. Milk yield, fat and protein contents, and F:P were normally distributed (data not shown).

\section{Genetic Parameters}

Considering the coefficient of variation calculated from the 4,500 Gibbs samples of each trait, the effect accounting for the greatest variation among samples was the classifier $(\mathrm{CV}=32.0 \%)$, followed by the additive genetic $(8.7 \%)$, the HYS $(3.3 \%)$, and the residual (1.4\%) effects. Locomotion had the highest coefficient of variation across the 4,500 Gibbs samples compared 

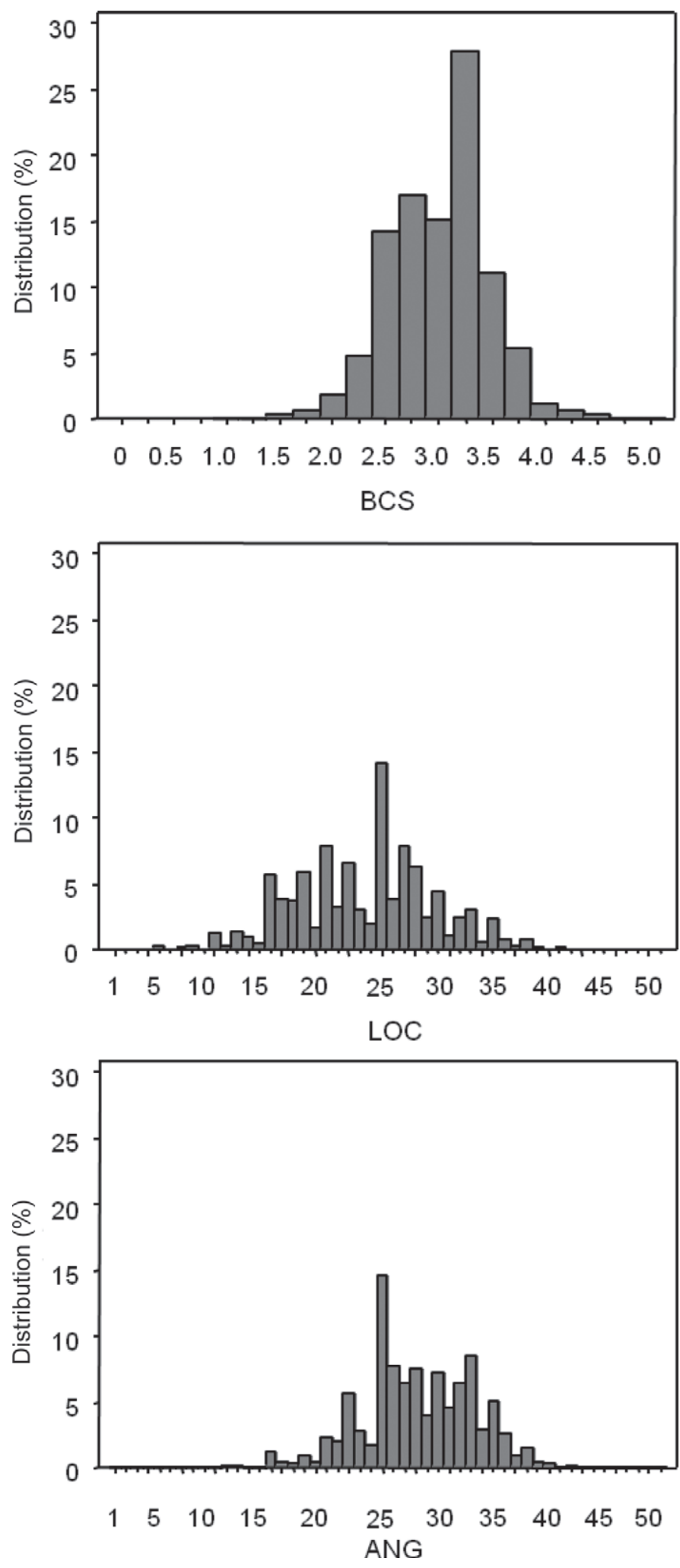

Figure 1. Distribution of raw phenotypes for BCS, locomotion (LOC), and angularity (ANG). with the other single-trait analyses. Analyses carried out using bivariate models produced similar estimates (results not shown). For all analyzed traits, the residual variance showed the lowest coefficient of variation calculated across the 4,500 Gibbs samples.

Heritability estimates for BCS, LOC, and ANG were $0.114(\mathrm{PSD} 95 \%=0.094-0.134), 0.049(\mathrm{PSD} 95 \%$ $=0.035-0.063)$, and $0.098(\mathrm{PSD} 95 \%=0.081-0.116)$, respectively (Table 2). Regarding production traits, protein and fat content exhibited the highest heritability, namely 0.251 (PSD95\% $=0.226-0.276$ ) and 0.163 (PSD95\% $=0.141-0.185)$, respectively, whereas MY and F:P had the lowest heritability, namely 0.108 (PSD95\% $=0.092-0.124)$ and $0.109(\operatorname{PSD} 95 \%=0.091-0.128)$, respectively (Table 2). The corresponding within-herd heritabilities were 0.158 (PSD95\% $=0.134-0.182$ ) for BCS, 0.056 (PSD95\% $=0.040-0.072$ ) for LOC, 0.120 $(\mathrm{PSD} 95 \%=0.099-0.140)$ for $\mathrm{ANG}, 0.162(\mathrm{PSD} 95 \%=$ $0.138-0.185$ ) for MY, 0.343 (PSD95\% $=0.310-0.376$ ) for protein content, 0.216 (PSD95\% $=0.187-0.245)$ for fat content, and 0.141 (PSD95\% $=0.118-0.164$ ) for $\mathrm{F}: \mathrm{P}$ (data not shown).

The genetic correlation between BCS and LOC was weak $(-0.084)$ and not different from zero (Table 3 ). Body condition score showed a strongly negative genetic correlation with ANG ( -0.612$)$ and a moderately negative genetic correlation with MY $(-0.386)$, whereas genetic correlations of BCS with fat (0.094) and F:P $(-0.014)$ were very weak and not different from zero (Table 3). The genetic correlation between BCS and protein content (0.173) was weak, but different from zero. The genetic correlation between LOC and ANG was strongly positive (0.650) and moderately positive with MY (0.238), whereas the genetic relationships with fat content (0.071), protein content (0.028), and F:P (0.074) were weak and not different from zero. Phenotypic correlations were weak and generally smaller than their genetic counterparts. The estimates ranged from -0.241 (BCS with ANG) to 0.245 (LOC with ANG), and were of the same sign as the corresponding genetic correlations, with the exception of the relationships between BCS and MY, and BCS and LOC, which were also significantly different from zero.

\section{DISCUSSION}

Within-herd heritability estimates were greater than heritabilities, as the latter were calculated considering all estimated variance components in the denominator of the formula, whereas the former did not include HYS and CL variance components. The heritabilities for BCS were consistent with previous findings in Holstein cows. Estimates ranging from 0.10 to 0.34 were reported in literature by Pryce et al. (2000), Dechow et al. (2001), 
Table 2. Estimates of herd-year-season of classification $\left(\sigma_{\text {hys }}^{2}\right)$, classifier $\left(\sigma_{\mathrm{cl}}^{2}\right)$, additive genetic $\left(\sigma_{a}^{2}\right)$ and residual $\left(\sigma_{e}^{2}\right)$ variance, and heritability $\left(\mathrm{h}^{2}\right)$ for BCS, locomotion, angularity, milk yield, fat and protein contents, and fat to protein ratio $(\mathrm{F}: \mathrm{P})^{1}$

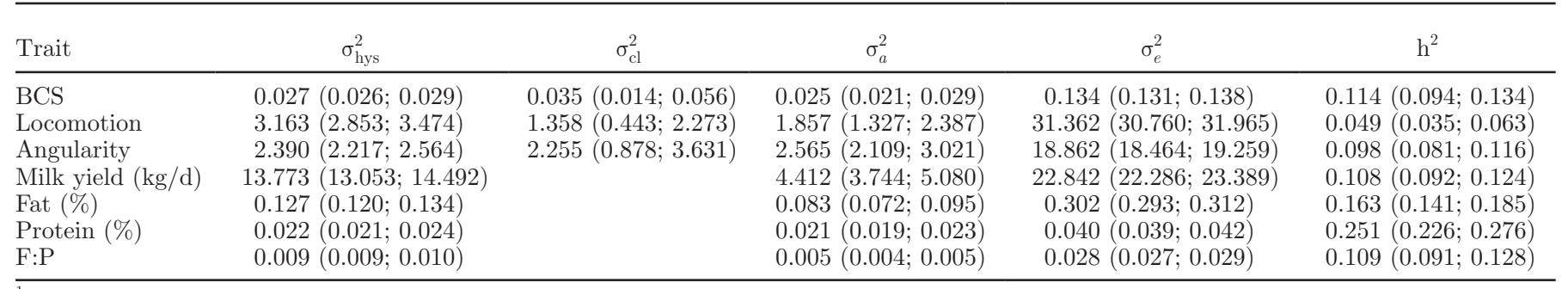

${ }^{1}$ The $95 \%$ posterior SD intervals for heritability are within parentheses.

Gallo et al. (2001), Van Dorp et al. (2004), Zink et al. (2011), and Buttchereit et al. (2012). In a recent study, Buttchereit et al. (2011) used random regression models to assess heritability of BCS across lactation for 682 first parity Holstein cows from a dairy research herd in Germany; the estimates decreased from 0.59 at the beginning of the lactation to 0.40 after 4 mo postcalving. Loker et al. (2011) estimated heritabilities for BCS that were between 0.14 and 0.26 using random regression models on field data recorded on first lactation Holsteins in Canada, with the highest values in midlactation and an average value of 0.22 . Dechow et al. (2004) suggested that BCS has the lowest heritability at early lactation and the highest at midlactation. Early lactation is a critical period for cows that experience a negative energy balance resulting in mobilization of body reserves (Roche et al., 2009). Loker et al. (2011) argued that the low heritability at this stage could be due to the importance of fat mobilization for cow metabolism. The ability to mobilize tissue reserves has been subjected to evolutionary pressures such that early lactation tissue mobilization has been genetically conserved. As reported by Van Dorp et al. (2004) and Dal Zotto et al. (2007), the discrepancies across studies regarding the heritability for BCS could be due to several factors, such as differences in scale used for scoring the traits, the statistical model, breeds, number of records per animal, accuracy and consistency among classifiers, data editing, and the method of calculating heritability. The additive genetic variances estimated in our study were similar to those of Loker et al. (2011) and Buttchereit et al. (2012). The estimates of Loker et al. (2011) ranged between 0.02 and 0.04, whereas that of Buttchereit et al. (2012) was 0.032. Conversely, the additive genetic variance for BCS of Italian Holsteins estimated by Gallo et al. (2001) using a repeatability animal model on test-day records was 0.044 , which is higher than our result. Possible reasons for this difference could be related to the data used to obtain the genetic variance. For instance, the study of Gallo et al. (2001) was based on a much smaller number of recorded animals (1,344 in 25 herds) than our work, and was conducted on different lactations and on repeated records collected by one classifier. Besides these differences, another key point could be the time span (10 yr) between the 2 studies and the genetic selection that occurred in this period. In particular, the selection to increase production traits and to obtain more dairy type cows (i.e., more angular) could have indirectly reduced genetic variance for BCS.

The heritabilities for LOC were slightly lower compared with findings of Boelling and Pollott (1998), Van Dorp et al. (2004), van der Waaij et al. (2005), Boelling et al. (2007), Onyiro and Brotherstone (2008), and Laursen et al. (2009), who reported estimates of heritability between 0.06 and 0.11 . The heritabilities for LOC were higher compared with Zink et al. (2011), who found a value of 0.03 in first-parity Czech Holsteins. The differences in heritability estimates likely depend on the trait definition (lameness or locomo-

Table 3. Estimates of genetic $\left(\mathrm{r}_{\mathrm{g}}\right)$ and phenotypic $\left(\mathrm{r}_{\mathrm{p}}\right)$ correlations of BCS and locomotion with angularity, milk yield, fat and protein contents, and fat to protein ratio $(\mathrm{F}: \mathrm{P})^{1}$

\begin{tabular}{lccrrr}
\hline & \multicolumn{2}{c}{ Body condition score } & & Locomotion \\
\cline { 2 - 3 } \cline { 5 - 6 } Trait & $\mathrm{r}_{\mathrm{g}}$ & $\mathrm{r}_{\mathrm{p}}$ & $\mathrm{r}_{\mathrm{g}}$ & $\mathrm{r}_{\mathrm{p}}$ \\
\hline BCS & - & - & & $-0.084(-0.271 ; 0.103)$ & $0.093(0.047 ; 0.138)$ \\
Angularity & $-0.612(-0.530 ;-0.694)$ & $-0.241(-0.189 ;-0.294)$ & & $0.650(0.521 ; 0.778)$ & $0.245(0.221 ; 0.269)$ \\
Milk yield (kg/d) & $-0.386(-0.291 ;-0.481)$ & $0.043(0.023 ; 0.064)$ & & $0.238(0.068 ; 0.407)$ & $0.132(0.107 ; 0.156)$ \\
Fat (\%) & $0.094(-0.008 ; 0.196)$ & $0.043(0.033 ; 0.054)$ & & $0.071(-0.117 ; 0.259)$ & $0.015(0.002 ; 0.027)$ \\
Protein (\%) & $0.173(0.086 ; 0.261)$ & $0.113(0.122 ; 0.144)$ & & $0.028(-0.145 ; 0.201)$ & $0.042(0.028 ; 0.055)$ \\
F:P & $-0.014(-0.129 ; 0.101)$ & $-0.016(-0.005 ;-0.026)$ & & $0.074(-0.123 ; 0.271)$ & $-0.004(-0.016 ; 0.008)$ \\
\hline
\end{tabular}

${ }^{1}$ The $95 \%$ posterior SD intervals for heritability are within parentheses. 
tion), the type of trait recorded (binary or continuous), the model used (threshold or linear), and the effects included in the analysis. Regarding the trait definition, LOC was mainly described either as the degree of lameness (Van Dorp et al., 2004) or as the walking ability of an individual, depending on the consequences of foot or leg disorders (Boelling and Pollott, 1998). In agreement with the national recording system, our study referred to the definition of LOC given by Boelling and Pollott (1998). Regarding the type of traits and the model applied, binary traits analyzed via threshold models using an underlying continuous scale instead of the observed binary scale have often reported greater values of heritability (Laursen et al., 2009). Onyiro and Brotherstone (2008) found that the type of housing and the amount of time spent in housing explained a significant amount of variation of LOC, but it is not always easy to get comprehensive information on these aspects during routine LOC collection. Another factor that could influence the estimation of heritability is the quality of trait recording, as the classifier could have a strong effect on the variability of the scored trait, especially when the trait is relatively new in the scoring system (Veerkamp et al., 2002). Interestingly, in the current study, classifier and LOC were respectively the effect and the trait with the greatest variation in Gibbs samples estimates.

Heritabilities estimated for ANG and production traits were lower than the official values reported by ANAFI (Interbull, 2012b). For ANG, the explanation could be the depth of data used. Specifically, the present study only used records from 2007 to 2012, whereas ANAFI used data since 1997 and assessed heritabilities using a multiple-trait animal model that includes all the conformation traits routinely recorded (Interbull, 2012b). Previous estimates of heritability for ANG were moderate and ranged from 0.19 to 0.33 (Pryce et al., 2000; Dechow et al., 2003; Zink et al., 2011). A slightly closer value to the heritability estimated for ANG in the current study was found by Van Dorp et al. (2004), who estimated a heritability of 0.11 for the trait. The low heritability for MY and fat and protein contents in the current study could be the consequence of using only one test-day record per cow, whereas the official analysis performed by ANAFI (2012a) used a random regression model including repeated records across lactations. The heritability of F:P was lower compared with Buttchereit et al. $(2011,2012)$ and Loker et al. (2012). Buttchereit et al. (2011) found heritabilities ranging from 0.20 to 0.54 for F:P, with the highest values at the beginning of lactation and at the end of the recording period. Loker et al. (2012) reported a heritability of 0.42 for $\mathrm{F}: \mathrm{P}$, which is much higher than our estimate. Buttchereit et al. (2012), using repeated records of $\mathrm{F}: \mathrm{P}$, found a heritability of 0.30 . As previously observed by Buttchereit et al. (2010), the high heritability of F:P in early lactation could be due to the large repeatability of this trait in this phase.

\section{Correlations Between BCS and LOC}

The phenotypic correlation between BCS and LOC was very weak (0.093) but different from zero, whereas the genetic correlation between these traits $(-0.084)$ was not different from zero. Van Dorp et al. (2004) found negative phenotypic $(-0.17)$ and genetic $(-0.27)$ correlations between BCS and LOC (scored on a reverse scale than ours), but with high standard error of estimate for the genetic relationship (0.14). Those authors concluded that, phenotypically, cows with high BCS also had better LOC (Van Dorp et al., 2004). Our phenotypic correlation would support this statement, but the correlation is very weak, so it is not possible to draw a clear conclusion from this result.

\section{Correlations of BCS with ANG and Production Traits}

The genetic correlation between BCS and ANG (dairy form) was strong and negative $(-0.612)$, confirming findings reported in the literature $(-0.47$ to -0.87 ) by Veerkamp and Brotherstone (1997), Dechow et al. (2003), and Dal Zotto et al. (2007), whereas the phenotypic relationship was much weaker $(-0.241)$.

The genetic correlation between BCS and MY was moderate and negative, indicating that cows that produce high levels of milk in early lactation are genetically inclined to have lower BCS. Phenotypically, the relationship between BCS and MY was close to zero. Overall, a range of moderate to weak negative genetic correlations between BCS and milk production have been reported in literature $(-0.13$ from Pryce and Harris, 2006; -0.40 from Dal Zotto et al., 2007; and -0.28 from Loker et al., 2012).

The genetic correlation between BCS and fat content was slightly positive and not different from zero, whereas the correlation between BCS and protein content was still slightly positive but different from zero. The respective phenotypic correlations were positive and different from zero. Loker et al. (2012) found similar genetic correlations of BCS with fat and protein content $(0.06$ and 0.23 , respectively, with a posterior SD of 0.05). The genetic correlation between BCS and F:P was negative but not different from zero, whereas the phenotypic correlation was slightly negative and different from zero. Buttchereit et al. (2011) found positive albeit not significant genetic correlations between BCS and F:P. Loker et al. (2012) found a genetic correlation of -0.12 between BCS and $\mathrm{F}: \mathrm{P}$, with a posterior $\mathrm{SD}$ 
of 0.06. Loker et al. (2012) analyzed the relationship between BCS and production traits using a random regression animal model; in early lactation, the genetic correlation of BCS was strong and negative with F:P, strong and positive with protein content, and weak and not significant for most of the lactation with fat content (Loker et al., 2012). Both BCS and F:P are indicators of cow energy status, and are expected to be negatively correlated. Due to high energy demand from increased milk production in early lactation, cows incur an energy deficit. Subsequently, lipolysis increases (reducing BCS) and mobilization of FA results in increased fat synthesis in the udder. At the same time, due to inadequate feed intake, insufficient protein synthesis could increase F:P (Grieve et al., 1986; Buttchereit et al., 2010). Loker et al. (2012) also showed that the correlation between BCS and protein, high and positive at the beginning of lactation, tends to reduce over time but remains positive, as a consequence of the change in cow metabolism. These previous findings could explain genetic correlations of the present work.

\section{Correlations of LOC with ANG and Production Traits}

The genetic correlation between LOC and ANG was high $(0.650)$, whereas the phenotypic correlation was weak $(0.245)$ but still positive and different from zero, indicating that angular cows had better locomotion, both genetically and phenotypically. Similar estimates were found by Berry et al. (2004), who reported a genetic correlation of 0.50 , but a phenotypic correlation equal to zero between LOC and ANG. Furthermore, Wright et al. (2013) estimated a genetic correlation of 0.40 between mobility and dairy form in Brown Swiss dairy cattle. Considering an opposite scale for LOC, Van Dorp et al. (2004) found very weak genetic $(-0.07)$ and phenotypic $(-0.01)$ correlations between LOC and dairy form, but they used data collected on different lactations. Boettcher et al. (1998) estimated an opposite and moderately strong genetic correlation between clinical lameness and dairy form, indicating that increased sharpness was associated with increased clinical lameness.

The genetic and phenotypic correlations between LOC and MY were moderately positive and different from zero, indicating that cows with good locomotion tend to produce more milk, which could mean that genetically healthier cows are better milk producers, have better walking ability, and are less genetically predisposed to diseases such as lameness (Van Dorp et al., 2004). Previous studies reported desirable relationships between traits related to locomotion (e.g., clinical lameness or feet and leg score) and milk production traits, even if low in magnitude (Boettcher et al., 1998;
Van Dorp et al., 2004; Pérez-Cabal et al., 2006). The genetic correlations of LOC with fat content, protein content, and F:P were weak and not different from zero, indicating that these traits are genetically independent. Despite results of the current study that showed favorable relationships between LOC, ANG, and MY, several studies reported that high-producing cows are more angular, with lower BCS, and more predisposed to disease than low-producing cows (Pryce et al., 1997; Zwald et al., 2004; Berry et al., 2011). Furthermore, locomotion was only recently introduced in the Italian Holstein type traits scoring system (ANAFI, 2012b), and thus it will be useful to confirm current estimates by reassessing (co)variance components when more data becomes available.

\section{CONCLUSIONS}

The additive genetic variances of BCS and LOC were weak but in agreement with the estimates reported in the literature. Body condition score and LOC seem to be genetically independent of each other, but further investigation of any departure from linearity of this relationship is needed. Body condition score showed a strong genetic correlation with ANG (its predictor). The genetic relationships of BCS and LOC with MY were moderate to low, indicating that high-producing cows tend to be thinner and have better locomotion than low-producing cows. The correlations of BCS and LOC with fat and protein content and F:P were almost negligible. Body condition score and LOC can be genetically improved, but before including these 2 traits in the selection index of the Italian Holstein breed, correlations with other traits currently used to improve type and functionality of cows need to be investigated.

\section{ACKNOWLEDGMENTS}

This study was supported by the Italian Holstein Friesian Cattle Breeders Association (ANAFI, Cremona, Italy), which funded a grant and provided data and pedigree information. The first author thanks Francesco Tiezzi (Department of Animal Science, North Carolina State University, Raleigh) for the worthwhile discussion on the paper. The useful comments and suggestions provided by 3 anonymous reviewers are gratefully acknowledged. M. Cassandro planned and supervised the research; M. Battagin performed the statistical analyses; M. Battagin and C. Sartori wrote the first draft of the manuscript; S. Biffani supplied data and gave support in model definition; $\mathrm{M}$. Penasa edited the manuscript. All authors contributed to the discussion of the results and commented on the manuscript. 


\section{REFERENCES}

ANAFI. 2012a. Average milk/fat/protein yield milk recorded HolsteinFriesian cows in Herd-Book Statistics 2011: Genetic Improvement Activities Holstein Breed. Accessed Sep. 18, 2012. http://www. anafi.it/english/.

ANAFI. 2012b. Type classification. Area of works. Accessed Sep. 18, 2012. http://www.anafi.it/valutazionimorfologiche/ispettoridirazza.htm.

Battagin, M., F. Forabosco, J. H. Jakobsen, M. Penasa, T. J. Lawlor, and M. Cassandro. 2012. International genetic evaluation of Holstein bulls for overall type traits and body condition score. J. Dairy Sci. 95:4721-4731.

Berry, D. P., M. L. Bermingham, M. Good, and S. J. More. 2011. Genetics of animal health and disease in cattle. Irish Vet. J. 64:5. http://dx.doi.org/10.1186/2046-0481-64-5.

Berry, D. P., F. Buckley, P. Dillon, R. D. Evans, and R. F. Veerkamp. 2004. Genetic relationships among linear type traits, milk yield, body weight, fertility and somatic cell count in primiparous dairy cows. Ir. J. Agric. Food Res. 43:161-176.

Boelling, D., A. Fogh, and U. Sander Nielsen. 2007. Locomotion as a new trait: First results from Denmark. Interbull Bull. 37:175-178.

Boelling, D., and G. E. Pollott. 1998. Locomotion, lameness, hoof and leg traits in cattle II. Genetic relationships and breeding values. Livest. Prod. Sci. 54:205-215.

Boettcher, P. J., J. C. M. Dekkers, L. D. Warnick, and S. J. Wells. 1998. Genetic analysis of clinical lameness in dairy cattle. J. Dairy Sci. 81:1148-1156.

Buttchereit, N., E. Stamer, W. Junge, and G. Thaller. 2010. Evaluation of five lactation curve models fitted for fat:protein ratio of milk and daily energy balance. J. Dairy Sci. 93:1702-1712.

Buttchereit, N., E. Stamer, W. Junge, and G. Thaller. 2011. Short communication: Genetic relationship among daily energy balance, feed intake, body condition score, and fat to protein ratio of milk in dairy cows. J. Dairy Sci. 94:1586-1591.

Buttchereit, N., E. Stamer, W. Junge, and G. Thaller. 2012. Genetic parameters for energy balance, fat/protein ratio, body condition score and disease traits in German Holstein cows. J. Anim. Breed. Genet. 129:280-288.

Dal Zotto, R., M. De Marchi, C. Dalvit, M. Cassandro, L. Gallo, P. Carnier, and G. Bittante. 2007. Heritabilities and genetic correlations of body condition score and calving interval with yield, somatic cell score, and linear type traits in Brown Swiss cattle. J. Dairy Sci. 90:5737-5743.

Dechow, C. D., G. W. Rogers, and J. S. Clay. 2001. Heritabilities and correlations among body condition scores, production traits, and reproductive performance. J. Dairy Sci. 84:266-275.

Dechow, C. D., G. W. Rogers, L. Klei, and T. Lawlor. 2003. Heritabilities and correlations among body condition score, dairy form and selected linear type traits. J. Dairy Sci. 86:2236-2242.

Dechow, C. D., G. W. Rogers, L. Klei, and T. J. Lawlor. 2004. Heritability and correlations for body condition score and dairy form within and across lactation and age. J. Dairy Sci. 87:717-728.

Edmonson, A. J., I. J. Lean, L. D. Weaver, T. Farver, and G. Webster. 1989. A body condition scoring chart for Holstein dairy cows. J. Dairy Sci. 72:68-78.

Gallo, L., P. Carnier, M. Cassandro, R. Dal Zotto, and G. Bittante. 2001. Test-day genetic analysis of condition score and heart girth in Holstein Friesian cows. J. Dairy Sci. 84:2321-2326.

Geman, S., and D. Geman. 1984. Stochastic relaxation, Gibbs distributions, and the Bayesian restoration of images. IEEE Trans. Pattern Anal. Mach. Intell. 6:721-741.

Grieve, D. G., S. Korver, Y. S. Rijpkema, and G. Hof. 1986. Relationship between milk composition and some nutritional parameters in early lactation. Livest. Prod. Sci. 14:239-254.

Interbull. 2012a. Evaluations. Mace evaluations. Conformation. January 2009. Accessed Oct. 2, 2012. http://www-interbull.slu.se/ conform/framesida-conf.htm.

Interbull. 2012b. Evaluations. National information. Description of the GES as applied in member countries. Italian Holstein pro- duction. Accessed Oct. 02, 2012. http://www-interbull.slu.se/ national_ges_info2/framesida-ges.htm.

Laursen, M. V., D. Boelling, and T. Mark. 2009. Genetic parameters for claw and leg health, foot and leg conformation, and locomotion in Danish Holstein. J. Dairy Sci. 92:1770-1777.

Loker, S., C. Bastin, F. Miglior, A. Sewalem, L. R. Schaeffer, J. Jamrozik, and V. Osborne. 2011. Short communication: Estimates of genetic parameters of body condition score in the first 3 lactations using a random regression animal model. J. Dairy Sci. 94:36933699 .

Loker, S., C. Bastin, F. Miglior, A. Sewalem, L. R. Schaeffer, J. Jamrozik, and V. Osborne. 2012. Genetic and environmental relationship between body condition score and milk production traits in Canadian Holsteins. J. Dairy Sci. 95:410-419.

Manson, F. J., and J. D. Leaver. 1988. The influence of concentrate amount on locomotion and clinical lameness in dairy cattle. Anim. Prod. 47:185-190.

Misztal, I. 2008. Reliable computing in estimation of variance components. J. Anim. Breed. Genet. 125:363-370.

Onyiro, O. M., L. J. Andrews, and S. Brotherstone. 2008. Genetic parameters for digital dermatitis and correlations with locomotion, production, fertility traits, and longevity in Holstein-Friesian dairy cows. J. Dairy Sci. 91:4037-4046.

Onyiro, O. M., and S. Brotherstone. 2008. Genetic analysis of locomotion and associated conformation traits of Holstein-Friesian dairy cows managed in different housing systems. J. Dairy Sci. 91:322-328.

Pérez-Cabal, M. A., C. García, O. González-Recio, and R. Alenda. 2006. Genetic and phenotypic relationships among locomotion type traits, profit, production, longevity, and fertility in Spanish dairy cows. J. Dairy Sci. 89:1776-1783.

Pryce, J. E., M. P. Coffey, and S. Brotherstone. 2000. The genetic relationship between calving interval, body condition score and linear type and management traits in registered Holsteins. J. Dairy Sci. 83:2664-2671.

Pryce, J. E., and B. L. Harris. 2006. Genetics of body condition score in New Zealand dairy cows. J. Dairy Sci. 89:4424-4432.

Pryce, J. E., R. F. Veerkamp, R. Thompson, W. G. Hill, and G. Simm. 1997. Genetic aspects of common health disorders and measures of fertility in Holstein Friesian dairy cattle. Anim. Sci. 65:353-360.

Roche, J. R., N. C. Friggens, J. K. Kay, M. W. Fisher, K. J. Stafford, and D. P. Berry. 2009. Invited review: Body condition score and its association with dairy cow productivity, health, and welfare. J. Dairy Sci. 92:5769-5801.

van der Waaij, E. H., M. Holzhauer, E. Ellen, C. Kamphuis, and G. de Jong. 2005. Genetic parameters for claw disorders in Dutch dairy cattle and correlations with conformation traits. J. Dairy Sci. 88:3672-3678.

Van Dorp, T. E., P. Boettcher, and L. R. Schaeffer. 2004. Genetics of locomotion. Livest. Prod. Sci. 90:247-253.

Veerkamp, R. F., and S. Brotherstone. 1997. Genetic correlations between linear type traits, food intake, live weight and condition score in Holstein Friesian dairy cattle. Anim. Sci. 64:385-392.

Veerkamp, R. F., C. L. M. Gerritsen, E. P. C. Koenen, A. Hamoen, and G. De Jong. 2002. Evaluation of classifiers that score linear type traits and body condition score using common sires. J. Dairy Sci. 85:976-983.

WHFF (World Holstein Friesian Foundation). 2008. Progress of type harmonization. Accessed Sep. 18, 2012. http://www.whff.info/ info/typetraits/TypeHarmonisation_2009update.pdf.

Wright, J. R., G. R. Wiggans, C. J. Muenzenberger, and R. R. Neitzel. 2013. Short communication: Genetic evaluation of mobility for Brown Swiss dairy cattle. J. Dairy Sci. 96:2657-2660.

Zink, V., M. Štipková, and J. Lassen. 2011. Genetic parameters for female fertility, locomotion, body condition score and linear type traits in Czech Holstein cattle. J. Dairy Sci. 94:5176-5182.

Zwald, N. R., K. A. Weigel, Y. M. Chang, R. D. Welper, and J. S. Clay. 2004. Genetic selection for health traits using producerrecorded data. II. Genetic correlations, disease, probabilities, and relationships with existing traits. J. Dairy Sci. 87:4295-4302. 